\title{
Ciało - źródło grzechu czy powód do chwały w świetle poglądów Tertuliana
}

\section{Wprowadzenie}

Sfera ludzkiej cielesności budziła na przestrzeni wieków szereg kontrowersji natury filozoficznej, często prowadząc do pogardy ciała, zanegowania jego godności, wskazania, iż stanowi ono źródło zła i grzechu. Pojawiały się także tendencje przeciwne, prowadzące do hołubienia ludzkiego ciała i wynoszenia na piedestał sfery cielesności. Rodzi się pytanie, jakie było w tej kwestii stanowisko pierwotnego chrześcijaństwa, które musiało stawić czoła różnorakim nurtom starożytnej myśli filozoficznej, w szczególności gnozie, która stawała się zagrożeniem wewnątrz samego chrześcijaństwa. Należy stwierdzić, że powyższe problemy wiążą się z określeniem istoty człowieka i odpowiedzią na podstawowe pytania antropologii filozoficznej: kim jest człowiek, co go stanowi, jaka jest jego ontyczna struktura?

Niemal każdy kierunek filozoficzny prezentuje własną koncepcję człowieka, ale pomimo różnic zasadniczo zarysowują się trzy możliwości: można w człowieku uznawać tylko ciało, tylko duszę, albo jednocześnie ciało i duszę․ Pozwala to wyodrębnić monizm psychofizyczny, według którego człowieka stanowi tylko jedna substancja, a zjawiska fizyczne i psychiczne są przejawami tej jednej substancji i zróżnicowanie pomiędzy nimi jest tylko pozorne ${ }^{2}$. W zależności od tego czy tą jedną substancją jest dusza, ciało, substancja boska, czy też ich wzajemna tożsamość wyróżnia się: monizm spirytualistyczny (idealistyczny) ${ }^{3}$, monizm ma-

Por. G. DogIel, Antropologia filozoficzna, Kraków 1992, s. 126; C.E. Freppel, Tertullien. Cours d’éloquence sacrée fait à la Sorbonne pendant lannée 1861-1862, Paris 1887, dz. cyt., s. 323-324.

2 Na temat monizmu i jego krytycznej oceny por.: G. DoGIEL, Antropologia filozoficzna, dz. cyt., s. $127-128$.

3 Według tego ujęcia człowieka stanowi tylko dusza, ciało zaś i zjawiska fizyczne są jedynie przejawami duszy, jej epifaniami. 
terialistyczny ${ }^{4}$, monizm panteistyczny ${ }^{5}$ oraz teorię identyczności (tożsamości) ${ }^{6}$.

Dualizmem psychofizycznym określa się poglądy uznające w człowieku ciało i duszę, ale jako dwie zupełne i samowystarczalne substancje, pomiędzy którymi istnieje jedynie luźny związek przypadłościowy, albo w następstwie pewnego przewinienia, albo wzajemnego oddziaływania, jakiejś interwencji Bożej, albo ustalonego z góry porządku; między duszą i ciałem oraz zjawiskami psychicznymi i fizycznymi zachodzą istotne różnice ${ }^{7}$. Moźna zatem wyróżnić np.: dualizm Platona, Kartezjusza, Leibniza, okazjonalizm ${ }^{8}$, a także tzw. paralelizm psychofizyczny?.

Poglądy wyrastające na tle filozofii perypatetyczno - tomistycznej przyjmują teorię jedności substancjalnej duszy i ciała. Istotnymi elementami ontycznej struktury bytu ludzkiego są tu ciało i dusza tworzące jedność substancjalną. Ciało i dusza, jako dwie substancje niezupełne łącząc się ze sobą tworzą jedną substancję zupełną, czyli jeden całkowity byt substancjalny. Jednością substancjalną w przeciwieństwie do przypadłościowej określa się zatem jedność pomiędzy dwiema substancjami niezupełnymi, które łącząc się ze sobą tworzą jeden substancjalny byt, jedną substancję zupełną ${ }^{10}$. Winny być przy tym spełnione trzy

4 Monizm materialistyczny uznaje jedynie rzeczywistość materialną, wobec czego czlowieka stanowi tylko ciało, dusza natomiast (o ile ją przyjmuje) i zjawiska są przejawami i funkcjami materii.

5 Według tego ujęcia ciało i dusza oraz zjawiska fizyczne i psychiczne nie różnią się między sobą, lecz są przejawami jednej i jedynej substancji boskiej - Absolutu; ciało rozpatrywane jest od strony atrybutu rozciągłości, dusza od strony atrybutu myśli (por. np. poglądy Spinozy).

6 Teoria ta reprezentowana przez wspólczesnych badaczy (por. np.: J. Mond, K.E. Zimen, B. Reusch, H. Feigl) wysuwa hipotezę o tożsamości materii i ducha, ciała i duszy, zjawisk fizycznych i psychicznych, a także procesów psychicznych i neurofizjologicznych; krytykuje filozofię za utrzymywanie dualizmu w człowieku, nieliczenie się z osiągnięciami dzisiejszych nauk szczegółowych, jak np. neurologii, gdzie życie duchowe i świadomość człowieka utożsamia się z procesami mózgu. Por. T. WoJciechowski, Z problematyki duszy i ciała: teoria identyczności, "Analecta Cracoviensia", 14 (1982), s. 200-211.

7 Por. G. Dogiel, Antropologia filozoficzna, dz. cyt., s. 128-131; Chripaz F., Ciało, (ttum. J. Migasiński), Warszawa 1998, s. 93-100.

8 Okazjonalizm głosi, iż ciało i dusza jako dwie samodzielne substancje, nie wpływają na siebie, podobnie jak nie wplywają na siebie, lecz tylko paralelnie obok siebie przebiegają zjawiska fizyczne i psychiczne. Odpowiedzialność między nimi jest wywołana przez interwencję Bożą i zmiany w jednej sferze są okazją dla Boga do wywołania zmian w drugiej (por. Malebranche, Geulinex).

9 Paralelizm psychofizyczny powstał $w$ drugiej połowie XIX w. i jest najnowszą formą dualizmu, przyjmowaną również przez psychologów (np. Wundt, Paulsen). Paralelizm psychofizyczny przyjmuje, że istnieją dwie odrębne, samodzielne sfery zjawisk fizycznych i psychicznych, pomiędzy którymi nie ma żadnego związku przyczynowego, ani wzajemnego wpływu; zjawiska te przebiegają obok siebie paralelnie, każdemu zjawisku fizycznemu odpowiada zjawisko psychiczne i odwrotnie; por. G. DogIEL, Antropologia filozoficzna, dz. cyt., s. 130.

10 Por. G. DogIEL, Antropologia filozoficzna, dz. cyt., s. 132. 
warunki, aby mogła być utworzona jedność substancjalna: - obydwa byty wchodzące w skład związku muszą być substancjami, a nie przypadłościami; - obydwa byty muszą być substancjami niezupełnymi, ponieważ substancje zupełne nie potrzebują i nie mogą łączyć się z innymi, gdyż są samowystarczalne i posiadają wszystko, co jest im niezbędne do istnienia i działania (nie mogą stworzyć substancji o nowym istnieniu i nowej przynależności gatunkowej); - jedna z tych substancji winna mieć charakter potencjalny, druga charakter aktu, będąc czynnikiem determinującym i organizującym, w następstwie czego przy połączeniu z pierwszą substancją powstaje jedna substancja zupełna, posiadająca wspólne istnienie i przynależność gatunkową ${ }^{11}$.

\section{Pogarda ciała w starożytnej myśli filozoficznej}

Pierwsze koncepcje duszy ludzkiej i ciała w kręgu kulturowym Europy wiążą się z greckimi wierzeniami przedorfickimi i orfickimi ${ }^{12}$. Wniosły one elementy nowego wzorca kultury, według których zaczęto mówić o obecności czegoś boskiego w człowieku, boskiej cząstki (daimon), która ma naturę przeciwną ciału i nie jest śmiertelna ${ }^{13}$. Orficka antropogeneza opiera się na teogonii DionizosaZagreusa, syna Zeusa, który miał po nim panować nad światem. Bogini Hera nasłała jednak tytanów, ci Dionizosa schwytali, poćwiartowali, ugotowali w kotle, a następnie zjedli. Jedna z bogiń uratowała serce Dionizosa, dzięki czemu mógł on wielokrotnie odradzać się i wcielać. Zeus za karę poraził tytanów piorunem. To z ich popiołów powstał człowiek, który nosi w sobie podwójną naturę, tę złą - cielesną, powstałą z popiołów tytanów oraz dobrą - duchową, wywodzącą się od Dionizosa ${ }^{14}$. W człowieku zatem dochodzi nieustannie do ścierania się duszy z ciałem, czyli zmagań pomiędzy pierwiastkiem boskim (dziedzictwo boskiego, odradzającego się nieśmiertelnego Dionizosa) a pierwiastkiem cielesnym, będącym dziedzictwem zła i zbrodni. Człowiek zatem winien dążyć do wyzwolenia

11 Por. TAMżE, s. 132-134.

12 Wierzenia orfickie łączyły się z kultem Dionizosa i związane były z ruchem religijnym, odwołującym się do mitycznego śpiewaka i poety Orfeusza - jako inicjatora. Szczyt popularności przypada na przełom VII i VI w. p.n.e. Mitologia i literatura orficka (tzw. Hymny orfickie) zawiera swoistą teogonię, mającą przedłużenie w kosmogonii i specyficznej antropologii; por. D. DembińsKa, orfizm, w: Slownik pojęć filozoficznych, red. W. KRAJEwski, Warszawa 1996, s.143. Szerzej na temat orfizmu i związanej z nim mitologii, teogonii i antropologii por. M. ELIADE, Historia wierzeń i idei religijnych, Warszwa 1994, t. II, s. 121-135; G. REALE, Historia filozofi starożtnej, Lublin 1994, t. I, s. 447-465.

13 Por. G. Reale, Historia filozofii starożytnej, dz. cyt., t. I, s. 50, 451. Powstała pierwsza dualistyczna koncepcja duszy (daimon) i ciała (miejsce, gdzie dusza pokutuje), człowiek zaczyna dostrzegać w sobie dwie zwalczające się zasady i zaczyna rozumieć, że skłonności, które w sobie nosi, musi czasem powstrzymywać czy tłumić, bo nie wszystkie są dobre.

14 Por. J. Kosiewicz, Myśl wczesnochrześcijańska i katolicka wobec ciała, dz.cyt., s 19. 
pierwiastka boskiego z cielesnego więzienia. Pełne wyzwolenie może dokonać się jednak stopniowo, po kolejnych wcieleniach duszy na drodze metempsychozy. Pełne wartościowanie ludzkiego życia i rozrachunek za poczynione dobro i zło zostaje przeniesione w plan eschatologiczny. Po śmierci bowiem dokona się osąd i wyrównanie wszelkich krzywd; całkowite oczyszczenie jest też możliwe dopiero po ostatnim wcieleniu ${ }^{15}$.

O tym, że ciało było więzieniem i grobem, w który dusza popadła na skutek pierwotnej winy, wyraźne daje świadectwo Platon w Kratylosie:

Bo niektórzy wyjaśniają, że ciało (soma) jest grobem (sema) duszy, gdzie ona przebywa w tym życiu. A ponieważ poprzez ciato siebie okazuje, dając znak (semainei) o sobie, dlatego zostało trafnie nazwane znakiem (sema). Moim zdaniem głównie orficy wprowadzili te nazwę, bo wedlug nich dusza w ciele odbywa pokutę za winy, majac ciało za mocna osłonę, podobnq do więzienia, aby się w nim zachować (sozetai), dopóki nie odkupi win, i stad nazwa to soma (przechowanie, ostona), i nie ma potrzeby wprowadzania tutaj ani jednej litery ${ }^{16}$.

To dusza psyche-daimon przychodziła $\mathrm{z}$ kosmosu ${ }^{17} \mathrm{i}$ do niego wracała, podczas snu błąkała się po przestworzach. Uwięziona w ciele dusza miała rozluźniać z nim swe związki i od niego uwalniać, dlatego jej prawdziwa natura ujawniała się w czasie snu ciała, lub gdy ciało było bliskie śmierci. Możemy o tym przeczytać u Pindara:

Ciało każdego śmierci ulega przemożnej,

Lecz pozostaje kształt życia znikomy:

On jeden bowiem jest dany od bogów.

Śpi, kiedy członki nasze się trudzq,

A gdy uśniemy - w snach wielu wyjawia

Czekający nas trudów i radości wymiar ${ }^{18}$.

15 Por. TAMŻE, s. 20.

16 Platon, Kratylos, 400c. Winę pierwotną miałby wyjaśniać mit Dionizosa i Tytanów z teogonii Hezjoda, tłumaczący obecną w ludziach stałą skłonność do dobra i do zła: ludzie powstali z prochów Tytanów porażonych piorunem przez Zeusa za pożarcie jego syna Dionizosa; dusza stanowi część dionizyjską w czlowieku i z nią wiąże się skłonność do dobra, ciało jest częścią tytaniczną i z nim wiąże się zło. Por. G. ReAle, Historia filozofii starozytnej, dz. cyt., t. I, s. 463.

17 Orficy prawdopodobnie uznawali też preegzystencję dusz; w De anima A 5, 410 b 27 - 411 a 1 Arystotelesa możemy przeczytać: „Te same zastrzeżenia budzi także teoria [duszy] w poematach zwanych orfickimi; głosi ona mianowicie, że dusza unoszona wiatrami wchodzi ze wszechświata do wnętrza w procesie oddychania. Nie może to jednak zachodzić w roślinach i niektórych zwierzętach, nie wszystkie [ $z$ nich] bowiem oddychają. Uszło to uwagi zwolenników tej teorii". Natura duszy była powietrzem, tchnieniem, por. F. SARRI, Socrate e la nascità del concetto occidentale di anima, introduzione di G. Reale, Milano 1997, s. 79.

18 Pindar, fr. 131 b Snell (tłum, J. Danielewicz), za: G. REALE, Historia filozofii starożytnej, dz. cyt., t. I, s. 451 . 
Przez ascezę i zmaganie się ze złem dusza ulegała oczyszczeniu, czemu służyły także określone ryty i praktyki religijne ${ }^{19}$, a przez transmigrację i metempsychozę stopniowo dorastała do Królestwa Błogosławionych ${ }^{20}$. Orficy wyznawali zatem wiarę w reinkarnację jako formę pokutowania duszy i wszystkim ludziom, zależnie od tego, jakie prowadzili życie, należała się nagroda lub kara. Był to aspekt o charakterze wyraźnie moralnym ${ }^{21}$.

We wczesnym chrześcijaństwie, jak wskazuje J. Kosiewicz, wykształciły się, ścierające się ze sobą do czasów współczesnych, dwie przeciwstawne tendencje w pojmowaniu ontologii człowieka: jedna oparta na orientacji orficko-platońsko-gnostyckiej i druga zakorzeniona w Starym i Nowym Testamencie ${ }^{22}$.

Czerpiący z orfizmu i platonizmu gnostycyzm podważał jakiekolwiek pozytywne znaczenie ciała w procesie zbliżania się do Boga. Ciało rozumiane było jako przeszkoda i ograniczenie, przekleństwo człowieka oraz źródło wszelkiego zła i nieszczęść. Akcentowano głównie idealny i boski charakter duszy ludzkiej, dzięki której jednostka ludzka, spełniając wiele warunków, mogła osiągnąć szczęście i zbawienie. Taka wizja człowieka pogłębiała antropologiczną dwoistość i poszerzała rozziew między przyrodniczą strukturą podmiotu, jego związkami ze światem doczesnym a nadprzyrodzonymi właściwościami duszy, której głównym celem było jak najszybsze wyzwolenie się z okowów cielesności, aby zbliżyć się do Boga i osiągnąć zbawienie, pełnię niebiańskiej szczęśliwości w świecie bytów idealnych ${ }^{23}$. Powyższy nurt antropologiczny utrwalał i wzmacniał ontologiczny rozdźwięk między cielesnością a teocentryczną teologią duszy, której celem jest jedność z Bogiem ${ }^{24}$. Antynomiści odrzucali prawo moralne i jego powszechne obowiązywanie. Marcjon i jego zwolennicy wszelkie zło przypisywali materii przeciwstawiając ją duchowi. Negowali cielesność, odrzucali małżeństwo i prokreację, aby zapobiec pomnażaniu materialnego i cielesnego zła i nie przyczyniać się do utrwalania świata upadłego ${ }^{25}$. Podobnie jak bazylidianie, wyznawali doketyzm. Chrystus miał pozorne ciało, pozornie zatem cierpiał i pozornie umarł. Zbawienie dotyczy tylko duszy, a nie ciała, które ulega rozkładowi. Bazylidianie więc uważali, że wszelkie czyny, nawet największa rozpusta, są sprawą zupełnie

19 O oczyszczeniach w orfiźmie por. G. REALE, Historia filozofii starozytnej, dz. cyt., t. I, s. 464-465.

20 Por. TAMŻE.

${ }^{21}$ Por. G. Reale, Historia filozofii starozytnej, dz. cyt., t. I, s. 457; por. Platon, Prawa IX, 870 d-e; IX $872 \mathrm{~d}-\mathrm{e}$.

22 Por. J. Kosiewicz, Myśl wczesnochrześcijańska i katolicka wobec ciała, Warszawa 1998, s. 52-53.

23 Por. TAMżE, s. 52-53.

24 Na temat zagrożeń dualizmu gnostyckiego por. R. Cantalamessa, La cristologia di Tertulliano, Friburgo Svizzera 1962, s. 119-120.

25 Por. J. Kosiewicz, Myśl wczesnochrześcijańska i katolicka wobec ciała, dz.cyt., s. 58. 
obojętną ${ }^{26}$. Zwolennicy Apellesa uznawali preegzystencję dusz, które na skutek podszeptów Demiurga upadły i za karę zostały wtrącone w ciała, które są ziemskim więzieniem. Wyzwoleniem jest śmierć, ciało jednak nie może zostać zbawione i jest skazane na potępienie ${ }^{27}$.

Teksty Pisma świętego wskazują na dwudzielny charakter ontologii człowieka, ale także na wzajemnie dopełniające się właściwości ciała i duszy, dwóch najistotniejszych komponentów jednostki ludzkiej. Drugi zatem kierunek w antropologii chrześcijańskiej zwany biblijnym, znosi fundamentalną nieprzystawalność oraz napięcie i dysharmonię pomiędzy ciałem i duszą. Zdaniem przedstawicieli tego punktu widzenia, zarówno ciało jak i dusza są niezbędne do spełnienia warunków, jakie Bóg stawia w drodze do zbawienia. Przyrodnicza odnowa, odrodzenie cielesne, a więc i zmartwychwstanie ciała jest konieczne, aby człowiek (ciało i dusza) mógł być kiedyś osądzony, nagrodzony lub ukarany za postępowanie w życiu doczesnym ${ }^{28}$.

Ogólnie rzecz ujmując, jak zaznacza J. Kosiewicz, wśród wczesnochrześcijańskich rozważań trudno jest wyróżnić poglądy, które można byłoby w pełni i bez wątpliwości w całości przypisać do jednej bądź drugiej tendencji antropologicznej. Dochodziło do łączenia różnych trendów, założeń i interpretacji, niejednokrotnie ze sobą sprzecznych. Najczęściej występowały refleksje o charakterze mieszanym, w których przeważała jedna bądź druga tendencja ${ }^{29}$. W niniejszym opracowaniu podjęto próbę przedstawienia, jakie było w tych kwestiach stanowisko Tertuliana, ważnego chrześcijańskiego apologety z przełomu II i III wieku. Jest to tym bardziej interesujące, że w wielu opracowaniach poglądy tego pisarza są pomijane, sprawiając wrażenie, jakby na gruncie chrześcijańskiej literatury łacińskiej wszystko rozpoczynało się dopiero od św. Augustyna.

\section{Godność ciała ludzkiego w ujęciu Tertuliana}

Należy podkreślić, że Tertulian zawsze bronił jedności substancjalnej duszy i ciała, które stanowią człowieka. C. Munier stwierdza jednak, że Tertulian nie wypracował dokładnej idei jedności substancjalnej duszy i ciała, takiej jak opisuje Arystoteles czy scholastycy ${ }^{30}$, a swoją teorię opierał w tym zakresie na myśli

26 Por. F. Drączkowski, Patrologia, Pelplin-Lublin 1998, s. 91.

27 Por. J. Kosiewicz, Myśl wczesnochrześcijańska i katolicka wobec ciała, dz.cyt., s. 59.

28 TAMŻE, s. 52-53.

29 TAMżE, s. 54.

30 Por. Tertullien. La pénitence, Introduction, texte critique, traduction par C. Munier, Paris 1984, s. 204. Jako źródło dla prowadzonych rozważań wykorzystano krytyczne wydanie pism Tertuliana w serii Corpus Christianorum. Series Latina, t. 1-2, Turnholti 1954 (oznaczone dalej skrótem: CCL). 
i terminologii stoickiej ${ }^{31}$. Wynikałoby z tego, jak zaznacza C. Micaelli, pewne wahanie się w definicji bytu ludzkiego, który raz jest określany poprzez ciało, innym razem przez duszę ${ }^{32}$. Można to zauważyć chociażby w De resurrectione mortuoru$m^{33}$ czy w De carne Christi ${ }^{34}$. Nie ma tu jednak sprzeczności, ani jakiejś niepewności myśli ze strony Tertuliana. Wahania te były powodowane wymaganiami polemiki i potrzebą podkreślenia jednego lub drugiego aspektu rzeczywistości. Należy więc przyznać rację J.P. Mahé, że wyrażenia polemiczne nie wyrażają myśli naszego Autora w sposób całościowy ${ }^{35}$.

Mówiąc o jedności substancjalnej duszy i ciała należy rozumieć, że nie chodzi tu o jedność numeryczną w sensie matematycznym, kiedy można coś dodawać i odejmować. Wówczas bowiem dusza i ciało byłyby czymś jednym i tożsamym, o jednej wspólnej substancji. Tertulianowi chodzi natomiast o ścisłe zjednoczenie duszy i ciała, które nie dotyczy pojedyńczości, ale wzajemnej łączności obu substancji $i^{36}$.

Swoją koncepcję antropologiczną Tertulian wyprowadza z Księgi Rodzaju, z opisu stworzenia człowieka ${ }^{37}$. Istotna jest dobroć i miłość Boga objawiająca się w akcie stworzenia, jak również to, że Bóg osobiście formuje glinę i tchnie w nią, powołując człowieka do istnienia i dając mu zarazem miejsce najwyższe w świecie. Pozwala to ukazać między innymi godność ciała ludzkiego ${ }^{38}$ :

Czy rzeczywiście jest czymś dziwnym myśleć, że ciało ukształtowane przez Boga mogloby bezpośrednio otrzymać konsystencję bez żadnej dalszej ingerencji? Chodzi zatem o wielkg godność tego, co zostało utworzone z tej właśnie materii. Dlatego (ciało) tak dalece jest uhonorowane, jak dalece doznaje działania rąk Bożych, dopóki jest dotyka-

31 Por. R. Cantalamessa, La cristologia di Tertulliano, dz. cyt., s. 138-141.

32 Por. Tertulliano, La resurrezione dei morti, Traduzione, introduzione e note di C. MicaELli, Roma 1990, s. 15.

33 Por. De resurrectione mortuorum 5, 8, CCL 2, s. 927; 34, 10, CCL 2, s. 965-966.

34 Por. De carne Christi 5, 6, CCL 2, s. 881: Nisi si aut aliud est homo quam caro; 12, 1, CCL 2, s. 896: Quamquam in hoc vana distinctio est, quasi nos seorsum ab anima simus, cum totum quod sumus anima sit.

35 Por. Tertullien, La Chair du Christ, Introduction, texte critique, traduction et commentaire par J.P. Mahé, t. 2, Paris 1975, s. 374; R. Cantalamessa, La cristologia di Tertulliano, dz. cyt., s. 141.

${ }^{36}$ Na tej samej zasadzie Tertulian thumaczy jedność osób w Trójcy Ŝwiętej, por. Adversus Praxean 22, 11, CCL 2, s. 1191; por. też: H. PIETras, Wprowadzenie. Początki sporów o Trójcę Święta, w: Trójca Święta. Tertulian, Przeciw Prakseaszowi. Hipolit, Przeciw Noetosowi, Żródła Myśli Teologicznej 4, Kraków 1997, s. 18.

37 Por. Rdz 1, 26n; 2, 7.

38 Por. J. Alexandre, Une Chair Pour La Gloire. Lanthropologie faliste et mystique de Tertullien, Paris 2001, s. 136-141. 
ne, ujmowane, formowane i ksztaltowane. Rozważ, Bóg w całości się nim zająt i poświęcił, rękoma, zamystem, praca, rozumem, mądrościa, opatrznością, a nade wszystko miłościa, która wytyczala sylwetkę. Cokolwiek Bóg mialby odcisnąć z mutu, miat na względzie Chrystusa, który miat stać się człowiekiem, to znaczy tym samym mulem, $z$ którego Stowo stałoby się ciałem, które teraz jeszcze było ziemiq ${ }^{39}$.

Podobnie wzniosłych określeń na temat ciała używa Tertulian odrzucając myśl o możliwości jego unicestwienia:

Nie może to być, nie może to być, aby Bóg pozwolił zaprzepaścić w śmierci wiecznej dzieto swoich rąk, wytwór własnego geniuszu, futeral swojego tchnienia, królowę swego trudu, dziedzica swojej szczodrobliwości, kapłana własnego kultu, żotnierza swojego świadectwa, siostrę swego Pomazańca ${ }^{40}$.

Przedstawiona interpretacja pozwoliła naszemu autorowi, w odróżnieniu od innych pisarzy chrześcijańskich, przypisać ciału (uformowanemu z gliny przez samego Boga) jakość obrazu Bożego ${ }^{41}$. Stwórca jako wzór przyjmuje w rzeczywistości model mającego nadejść Chrystusa ${ }^{42}$ i gdy kształtuje ziemię (glinę), tym samym Boże dzieło

39 De resurrectione mortuorum 6, 2-3, CCL 2, s. 927-928: Quid enim, si nullo amplius opere statim figmentum de contactu Dei constitisset? Adeo magna res agebatur quod ista materia extruebatur Itaque totiens honoratur, quotiens manus Dei patitur, dum tangitur, dum decerpitur, dum deducitur, dum effingitur. Recogita totum illi Deum occupatum ad deditum, manu sensu opere consilio sapientia providentia et ipsa inprimis adfectione, quae liniamenta dictabat. Quodcumque enim limus exprimebatur, Christus cogitabatur, homo futurus, quod et limus, et sermo caro, quod et terra tunc.

40 De resurrectione mortuorum 9, 2, CCL 2, s. 932: Absit, absit, ut Deus manuum suarum operam, ingenii sui curam, adflatus sui vaginam, molitionis suae reginam, liberalitatis suae heredem, religionis suae sacerdotem, testimonii sui militem, Christi sui sororem, in aeternum destituat interitum.

${ }^{41}$ Por. P. SinisCalCo, Ricerche sul «De resurrectione» di Tertulliano, Roma 1966, s. 120. W literaturze wczesnochrześcijańskiej z największym zachwytem o pięknie ciała ludzkiego wyrażał się Augustyn, por. A. ECKMann, Dobroć i piękno ludzkiego ciala w pismach świętego Augustyna, w: TENĖE, Symbol Apostolski w pismach świętego Augustyna, Lublin 1999, s. 149-156.

42 Por. De resurrectione mortuorum 6, 3-4, CCL 2, s. 928: Quodcumque enim limus exprimebatur, Christus cogitabatur, homo futurus, quod et limus, et sermo caro, quod et terra tunc. Sic enim praefatio patris ad filium: faciamus hominem ad imaginem et similitudinem nostram. Et fecit hominem Deus, id utique quod finxit, ad imaginem Dei fecit illum, scilicet Christi. Et sermo enim Deus, qui in effigie Dei constitutus non rapinam existimavit paria<ri> Deo; por. Adversus Praxean 12, 3-4, CCL 2, s. 1173; Adversus Marcionem V, 8, 1, CCL 1, s. 685. W cytowanych fragmentach wyraźne jest rozróżnienie jakie czynił Tertulian na similitudo (podobieństwo) i imago (obraz). Pierwsze utracone przez czlowieka na skutek grzechu pierworodnego, przywracane jest przez chrzest św., drugie trwa jako stałe jego uposażenie. Por. De baptismo 5, 7, CCL 1, s. 282; De exhortatione castitatis 1, 3, CCL 2, s. 1015. Por. C. SCANzILlo, Lanima nei Padri dei primi secoli, w: F. Battagla (ed.), Lanima, 1979, s. 70-81. 
(Dei opus) staje się obrazem Boga (pignus Dei) ${ }^{43}$. Stąd przede wszystkim wywodzi się godność ciała, że zostało ono powołane do uczestnictwa w podobieństwie Boga. Rzeczywistym twórcą ciała ludzkiego jest sam Bóg, nie może ono zatem być deprecjonowane, $\mathrm{z}$ racji, że pochodzi od Osoby tak bardzo godnej szacunku ${ }^{44}$ :

I to zdziałała dobroć najpracowitsza. Nie słowem rozkazujacym, ale ręka przyjazna, po uprzednim przymilnym stowie: „Uczyńmy człowieka na Nasz obraz i podobieństwo Nasze. Dobroć powiedziała, dobroć ulepiła z mułu tak wspaniała istotę cielesna, zjednej materii obdarzona tyloma zdolnościami; dobroć tchnęla i powstała dusza, nie martwa, ale żywa, i dobroć ja postawiła nad wszystkimi stworzeniami, którymi miata się żywić, nad którymi królować, nawet je nazywać; co więcej dobroć przydała człowiekowi rozkosze, aby do raju przeniesiony - już wtedy ze świata do Kościola - w jego przyjemnościach przebywat, jakby był posiadaczem całego świata. Ta sama dobroć zapewnita mu i pomoc, żeby mu nie brakowato czegoś dobrego ${ }^{45}$.

Wśród wypowiedzi Kartagińczyka dotyczących relacji między ciałem i duszą da się wyróżnić kilka grup. Pierwsza z nich obejmuje teksty określające ciało jako pomieszczenie i schronienie dla duszy ${ }^{46}$. Druga grupa dotyczy tekstów określających ciało jako narzędzie duszy ${ }^{47}$. Jeszcze inna grupa obejmuje wypowiedzi wynoszące ciało do większej godności i ukazujące je jako wspólnika i współdziedzica duszy ${ }^{48}$. Bez wątpienia myśl Tertuliana nie wyczerpuje się w tym zalkresie i choć nie definiuje w pełni natury relacji pomiędzy ciałem i duszą, pewne jest, że nie deprecjonuje jego wartości i nie pogardza nim. Wręcz przeciwnie, ukazuje godność ciała ludzkiego w oparciu o stwórcze działanie Boga i w połączeniu z chrystologią. Przeciwstawia się zatem starożytnym nurtom filozoficznym oraz chrześcijańskiej gnozie, czyniąc z ciała nie tylko istotny element ale także swoistą podstawę zbawienia (caro salutis est cardo) ${ }^{49}$.

43 Por. De resurrectione mortuorum 6, 5, CCL 2, s. 928: Ita limus ille iam tunc imaginem induens Christifuturi in carne non tantum Dei opus erat sed et pignus. Szerzej na temat stworzenia czlowieka na obraz i podobieństwo Boga w nauczaniu Tertulian por. J. Alexandre, Une Chair Pour La Gloire, dz. cyt., s. 157-165.

44 Por. S. STRĘKowsKi, Godność ciala w polemice Tertuliana przeciwko poglądom filozofów greckich na podstawie De resurrectione mortuorum, VoxP 22 (2002) t. 42-43, s. 380-381.

45 Adversus Marcionem II, 4, 4, CCL 1, s. 479 (tłum. PSP 58, s. 74).

46 Por. De resurrectione mortuorum 16, 11-12, CCL 2, s. 940: caro = vas (por. 1 Tes 4, 4) capacitatis nomine dicta est, qua animam capit et continet; $41,1 \mathrm{n}$., CCL 2, s. 975 : caro = terrena domus (2 Kor 5, 1); 46, 14, CCL 2, s. 984: anima = inquilina carnis; De anima 38, 4, CCL 2, s. 842: caro= domus animae; anima = inquilinus carnis; De anima 38, 6, CCL 2, s. 842, Scorpiace 12, 10, CCL 2, s. 1093: caro = vestitus animae.

47 Por. De anima 40, CCL 2, s. 843-844; De resurrectione mortuorum 16, CCL 2, s. 939-940; 63, CCL 2, s. 1011-1012: caro = supellex, instrumentum animae.

48 Por. De anima 58, CCL 2, s. 867-869; De resurrectione mortuorum 7, 13, CCL 2, s. 931: caro= consors, coheres animae.

49 Por. De resurrectione mortuorum 8, 1, CCL 2, s. 931; J. ALEXANDRE, Une Chair Pour La Gloire, dz. cyt., s. 140 . 
Zarówno kierunki gnostyckie przyjmujące podwójny schemat antropologiczny (dusza i ciało), jak też przyjmujące schemat potrójny ( $d u c h$, dusza i ciało), zgadzają się co do radykalnej opozycji pomiędzy ciałem materialnym i zmysłowym a iskrą ducha boskiego, jaka jest w nim zamknięta. Tyle, że według pierwszej teorii linia podziału przechodzi pomiędzy ciałem i duszą, podczas gdy według drugiej, linia ta dąży do oddzielenia ciała i duszy (zdegradowanej niemal do materii) od ducha ${ }^{50}$. Obie te koncepcje ostatecznie czerpią swój początek z dualizmu obecnego pierwotnie na obszarze kosmologii i teologii. Były one dobrze znane Tertulianowi ${ }^{51}$, który często dawał temu wyraz odnosząc się do nich w swoich dziełach, kiedy poruszał chociażby kwestie związane z boskim pochodzeniem duszy, jej nieśmiertelnością czy też wzajemną relacją do ciała ${ }^{52}$.

W teorii antropologicznej Tertuliana bardzo istotna jest jedność duszy i ciała. W De resurrectione mortuorum posłużyła ona do przedstawienia definicji człowieka, jako klamry spinającej ciało i duszę:

Dusza sama przez się nie stanowi człowieka [...] ani ciało bez duszy nie tworzy człowieka [...] w takim sensie terminem człowiek określa się, by tak rzec, owa klamrę, która jednoczy dwie substancje między soba połaczone, które w żaden sposób nie moga być oznaczone tym terminem, jeśli nie sq ze sobą ściśle powiązane ${ }^{53}$.

W innych wypowiedziach Tertulian zaznacza, że w takiego właśnie człowieka, określonego jako powiq̨zanie ścisłe ukonstytuowane z ciała i duszy wcielił się i objawił się Chrystus ${ }^{54}$. Warto w tym miejscu dodać, że według kartagińskiego pisarza, Zbawiciel przy wcieleniu przyjął ludzkie ciało i duszę ze wszystkimi ich

50 Por. M. Simonet ti, art. cyt., „Rivista di Storia e Letteratura Religiosa”, 2 (1966), s. 1n, 9 i 42; P. Siniscalco, Ricerche sul «De resurrectione» di Tertulliano, dz. cyt., s. 113-114.

51 Por. J. Alexandre, Une Chair Pour La Gloire, dz. cyt., s. 285.

52 Odnośnie do wieczności i boskiego pochodzenia duszy por. np.: De testimonio animae 1, 5, CCL 1, s. 176; odnośnie do koncepcji dualistycznej przeciwstawiającej duszę ciału por. np.: De resurrectione mortuorum 2, 2, CCL 2, s. 922; TAMŻE, 2, 4, CCL 2, s. 922; TAMŻE, 2, 12, CCL 2, s. 923-924; TAMżE, 4, 2, CCL 2, s. 925; odnośnie do nieśmiertelności duszy por. np.: De anima 4, 1, CCL 2, s. 786; TAMżE, 54, 1, CCL 2, s. 861; De resurrectione mortuorum 3, 2, CCL 2, s. 924.

53 De resurrectione mortuorum 40,3, CCL 2, s. 973: Porro nec anima per semetipsam homo [...] nec caro sine anima homo [...] Ita vocabulum homo consertarum substantiarum duarum quodammodo fibula est, sub quo vocabulo non possunt esse nisi cohaerentes. Por. C.E. FrepPEL, Tertullien, dz. cyt., s. 318-319; J. Alexandre, Une Chair Pour La Gloire, dz. cyt., s. 136.

${ }_{34}$ Por. De resurrectione mortuorum 34, 10, CCL 2, s. 965-966: Quid a Patre Christus, acceperat, nisi quod et induerat? Hominem sine dubio, carnis animaeque texturam. Neutrum ergo eorum, quae accepit, perire patietur, immo nec quidquam utriusque, immo nec modicum. 
właściwościami i władzami, oprócz skażenia grzechem ${ }^{55}$. Chrystus tak bardzo ukochał ludzkie ciało, że przyjął je, aby dokonać zbawienia świata ${ }^{56}$.

Dla kartagińskiego pisarza duch czy też umysł nie jest substancją różną od duszy. Co łacinnicy nazywają mens i grecy noàj, jest władzą, która rodzi się w duszy, rezyduje w niej i do niej należy. Substancja, która ożywia i czyni witalnym ciało, jest równocześnie centrum aktywności intelektualnej ${ }^{57}$. Błędem jest zatem upatrywanie różnego źródła dla siły witalnej i intelektualnej w człowieku. Dusza nadaje materii formę ciała zorganizowanego, które właśnie poprzez jedność z duszą otrzymuje specjalną aktywność witalną oraz intelektualną. Co ciekawe, dusza jednocząc się z ciałem nadaje mu szczególny indywidualny charakter, już nie tylko formę ogólną gatunku, ale człowieka jako konkretnej osoby ${ }^{58}$.

Jedność substancjalna duszy i ciała w człowieku, będąca owocem Boskiego dzieła stworzenia, jest tak silna, że może nastręczać trudności w ocenie prymatu i wzajemnej zależności obu tych substancji. Kwestię tę kartagiński autor podnosi w De resurrectione mortuorum:

Czy Bóg polożył duszę w człowieku, czy ja wlat, czy zmieszal z ciałem? Ich jedność jest tak znaczna, że powstaje niepewność, czy ciało jest nośnikiem duszy, czy dusza ciała, czy raczej ciało służy duszy, czy dusza ciału ${ }^{59}$.

Tertulian wyjaśnia, iż obie substancje są od siebie zależne i wzajemnie się dopełniają. Podobnie jak bez pomocy ciała dusza nie może cieszyć się naturą, korzystać z owoców świata i rozkoszować wonią rzeczy, tak poprzez tę duszę podtrzymywany jest cały integralny aparat zmysłowy wzroku, słuchu, smaku, za-

55 Por. R. Cantalamessa, La cristologia di Tertulliano, dz. cyt., s. 88-89; De carne Christi 13, 4, CCL 2, s. 898: In Christo vero invenimus animam et carnem simplicibus et nudis vocabulis editas, id est animam animam et carnem carnem, nusquam animam carnem aut carnem animam, quando ita nominari debuissent, si ita fuissent; De resurrectione mortuorum 49, 2, CCL 2, s. 990: Primus, inquit, homo de terra, choicus, id est limacius, id est Adam, secundus homo de caelo, id est sermo Dei, id est Christus, non alias tamen homo, licet de caelo, nisi quia et ipse caro atque anima, quod homo, quod Adam.

56 Por. S. stręKowski, Godność ciala w polemice Tertuliana, dz. cyt., VoxP 22 (2002) t. 42-43, s. $381,389$.

57 Por. C.E. Freppel, Tertullien, dz. cyt., s. 325.

58 Por. Tamże, s. 328-330; J. AleXandre, Une Chair Pour La Gloire, dz. cyt., s. 135.

59 De resurrectione mortuorum 7, 9, CCL 2, s. 930: (Deus) Collocavit autem an potius inseruit et inmiscuit carni? Tanta quidem concretione, ut incertum haberi possit, utrumne caro animam an carnem anima circumferat, utrumne animae caro an anima adpareat carni; por. także: TAMżE, 7, 10, CCL 2, s. 930: Sed etsi magis animam invehi atque dominari credendum est, ut magis Deo proximam, hoc quoque ad gloriam carnis exuberat, quod proximam Deo et continet et ipsius dominationis compotem praestat. 
pachu i dotyku ${ }^{60}$. Jedność duszy i ciała, która przejawia się w różnych funkcjach obu tych substancji, świadczy według Tertuliana o jedności człowieka. Człowiek bowiem, to nie tylko dusza jako nosicielka świadomości osobowej, ale również ciało $^{61}$. Tertulian ukazuje jak to ciało na poziomie egzystencjalnym i zarazem empirycznym ściśle jest związane $z$ duszą, tworząc całkowitą jedność pomimo różnicy ich funkcji:

Przez cialo dokonuja się wytwory sztuki, przez cialo studia, inwencje, dzieła, prace, obowiazki. Całe życie tak dalece jest zwiazkiem duszy i ciała, że nie żyć jest niczym innym dla duszy, jak pozostawać w odlączeniu od ciala. Tak samo zatem wlaściwa dla ciała jest śmierć jak $i \dot{z} y c i e$. Jeżeli wszystkie sprawy podporzadkowane sq duszy przy pomocy ciała, podlegaja także ciału. Wraz z tym się postugujesz, przy pomocy czego się posługujesz. Podobnie też ciało, dopóki jest poczytywane jako pomocnik i sługa duszy, i jest określane jako wspólnik i współdziedzic w sprawach doczesnych, dlaczegóżby nie w wiecznych?62.

Ciało zatem jest współpracownikiem i współdziedzicem duszy, gdyż cała działalność człowieka w rzeczywistości ziemskiej możliwa jest jedynie dzięki pośrednictwu ciala ${ }^{63}$. To w ciele dokonuje się sakramentalne obmycie wodami chrztu świętego, to w ciele dokonuje się uświęcenie człowieka ${ }^{64}$. Również wszelkie dobro dokonuje się w ciele i za pośrednictwem ciała, chociażby takie praktyki jak post, umartwienie, dziewictwo, wdowieństwo, wstrzemięźliwość, cierpienie, wyznanie wiary a nawet męczeństwo ${ }^{65}$. To wszystko wskazuje, że ciało wraz z duszą zasługuje na nagrodę, na zmartwychwstanie i udział w życiu wiecznym. Jednocześnie Tertulian dystansuje się także od tych, którzy nadmiernie uwielbiają ciało i hołdują

60 Por. TAMżE, 7, 11, CCL 2, s. 930.

${ }_{61}$ Por. P. Siniscalco, Ricerche sul «De resurrectione» di Tertulliano, dz. cyt., s. 115. W Adversus Marcionem I, 24, 5 (CCL 2, s. 467) i w De anima 9, 8 (CCL 2, s. 793) Tertulian pyta: Quid est autem homo aliud quam caro [...]?; i odnosi się do aktu stworzenia, kiedy Bóg wypełnia materię swym tchnieniem: [...] et corpulentia animae ex densatione solidata est et effigies ex impressione formata. Hic erit horno interior, alius exterior, dupliciter unus. Syntetycznie wyraża to w De resurrectione mortuorum 32, 8, CCL 2, s. 962: Tam enim corpus homo quam et anima, ut non possit altera species admittere aenigmata, altera exchudere.

62 De resurrectione mortuorum 7, 12-13, CCL 2, s. 931: Artes per carnem, studia ingenia per carnem, opera negotia officia per carnem, atque adeo vivere totum animae carnis est, ut non vivere aliud non sit animae quam a carne divertere. Sic etiam ipsum mori carnis est, cuius et vivere. Porro si universa per carnem subiacent animae, carni quoque subiacent. Per quod utaris, cum eo utaris necesse est. Ita caro, dum ministra et famula animae deputatur, consors et coheres invenitur, si temporalium, cur non et aeternorum?

63 Por. S. stręKowski, Godność ciala w polemice Tertuliana, dz. cyt., VoxP 22 (2002) t. 42-43, s. 381.

64 Por. De resurrectione mortuorum 8, 3, CCL 2, s. 931.

65 TAMŻE. 
mu. Według Afrykańczyka nikt nie żyje tak bardzo na sposób cielesny, jak ci, którzy nie uznają zmartwychwstania, pogardzają kara i dyscypliną ${ }^{66}$.

\section{Ludzkie ciało, a odpowiedzialność za zło i grzech}

Według Tertuliana jedność obu omawianych elementów ujawnia się także w przyjętej za stoikami zasadzie, że wszystko co istnieje jest ciałem, a zatem jak jest corpus carnis, tak jest również corpus animae ${ }^{67}$. Zasada ta pozwalając potwierdzić ścisły związek duszy i ciała jeszcze bardziej uwydatnia ideę jedności duszy i ciała w życiu i w działaniu, co będzie miało swoje konsekwencje także w odpowiedzialności za każdy czyn ludzki, dobry lub zły, a co za tym idzie, także w odpowiedzialności za grzech, we wspólnym udziale w sądzie i systemie kar oraz nagród w perspektywie eschatologicznej ${ }^{68}$. Idea tej współodpowiedzialności duszy i ciała, wyrastająca na bazie jedności substancjalnej człowieka, widoczna w De resurrectione mortuorum ${ }^{69}$, wyraźnie przedstawiona została wcześniej w De paenitentia:

Warto jednak zaznaczyć, że jedne grzechy dotycza ciala, sa to grzechy cielesne, inne zaś sa duchowe. Jest to oczywiste, ponieważ istota człowieka tkwi w zależności dwóch substancji, stąd też i grzeszy poprzez te elementy, z których się składa. Istotnej różnicy między tymi grzechami nie należy szukać w tym, że cialo i dusza sa dwiema rzeczami, bo jest wręcz przeciwnie, obydwa bowiem elementy tym bardziej sq sobie równe, że stanowia jednq istotę. Stad też nie wolno rozróżniać grzechy wedlug odmienności substancji i uważać, że jednej sa lżejsze, drugiej zaś cięższe [...] ponieważ w równym stopniu ciało i dusza należa do Pana, dlatego też każde z nich gdy grzeszy, w równym stopniu obraża Boga. Czy będziesz rozróżniać czyny ciała i ducha, których tak wielka jest lączność $i$ zażyly zwiazek tak w życiu jak $i$ w śmierci czy zmartwychwstaniu, że równo wtedy, albo do życia, albo na wyrok sqadu zostana wskrzeszone, ponieważ równo albo grzeszyly albo żyly niewinnie?; wspominamy o tym dlatego, by sobie uświadomić, że obydwa elementy czlowieka, jeśli któryś zawinit przed Bogiem, mają obowiazek pokuty. Wspólne jest bowiem dla obydwóch przewinienie, wspólny jest ich sędzia. Rozumie się Bóg; wspólne przeto i lekarstwo - pokuta. ${ }^{70}$

\footnotetext{
66 Por. S. strękowski, Godnośc ciala w polemice Tertuliana, dz. cyt., VoxP 22 (2002) t. 42-43, s. 382-383; De resurrectione mortuorum 11, 2, CCL 2, s. 933.

67 Por. TAmże, 32, 9, CCL 2, s. 964; A. Quaquarelli, Antropologia e escatologia secondo Tertulliano, „Rassegna di Scienze Filossofiche” 2 (1949), fasc. 2, s. 20 n.

68 Por. J. Alexandre, Une Chair Pour La Gloire, dz. cyt., s. 297.

${ }^{69}$ Por. De resurrectione mortuorum 15, 1-3, CCL 2, s. 937-938; тAмżE, 15, 5-6, CCL 2, s. 938; TAMżE, 33, 9, CCL 2, s. 964; TAMżE, 34, 1, CCL 2, s. 964.

${ }^{70}$ Por. De paenitentia 3, 3n, CCL 1, s. 324; tłum. PSP 5, s. 178.
} 
W kontekście powyższej wypowiedzi rodzi się pytanie o odpowiedzialność człowieka za czyny dokonane w ciele: czy to nie ciało wraz z jego pożądliwością i namiętnościami jest źródłem zła i grzechu? Tertulian wskazuje tu jednak na wolną wolę człowieka, która jawi się jako naturalna władza duszy. Hermogenes, Marcjon i gnostycy odrzucali wolność woli człowieka. Takie stanowisko mogło prowadzić jednak do zakwestionowania odpowiedzialności człowieka za jego czyny, słuszności dokonywania osądów, wyznaczania nagród i kar, a ciężar winy przenosiłoby nawet na samego Boga ${ }^{71}$. Tertulian nigdy nie kwestionował aspektu wolitywnego w człowieku i podkreślał zdolność duszy do wolnego osądu i wyboru. Szczególnie dał temu wyraz w Adversus Marcionem II 5-9. Wolność woli, według Kartagińczyka, należy do naturalnych władz duszy ${ }^{72}$ i jest jednym z czynników warunkujących Boże podobieństwo w człowieku:

Widzę, że Bóg stworzył człowieka wolnym i w jego sądzie, i w woli, iw możności wyboru, a nie spostrzegam żadnego innego podobieństwa do Boga i Jego obrazu jak właśnie ten stan i tę formę $e^{73}$.

Wolna wola warunkuje nie tylko Boże podobieństwo, ale także godność człowieka i jego wyższość nad światem, przez fakt uzyskania władzy nad sobą:

Wypadało przeto, by obraz i podobieństwo Boga byto obdarzone wolna wola i możnościa swego wyboru, na której to wolności i możności sam przez się obraz i podobieństwo do Boga zasadza. A do tego sama istota czlowieka jest przystosowana, aby byt takiego stanu, mianowicie wolny w wyborze i wladzy nad soba, dzięki tchnieniu Boga. Inaczej bowiem jakżeby to wygladało, aby czlowiek posiadajacy wladze nad calym światem nie miał najpierw władzy nad swoim rozumem i nie królował nad nim on jako pan nad innymi, stuga samego siebie? ?4.

Tertulian zaznacza, że człowiek z ustanowienia Bożego jest nastawiony na dobro, ale zarazem ma wolną wolę i może dokonywać wyboru, tak aby nie być niewolnikiem i sługą dobra. Tym większa zatem także zasługa człowieka, kiedy do-

71 Por. J. Alexandre, Une Chair Pour La Gloire, dz. cyt., s. 1165-172.

72 Por. De anima 21, 6, CCL 2, s. 814.

73 Adversus Marcionem II 5, 5, CCL 1, s. 480: Liberum et sui arbitrii et suae potestatis invenio hominem a Deo institutum, nullam magis imaginem et similitudinem Dei in illo animadvertens quam eiusmodi status formam (thum. PSP $58, \mathrm{~s}$. 74).

74 TAMŻE, II, 6, 3, CCL 1, s. 481: Oportebat igitur imaginem et similitudinem Dei liberi arbitrii et suae potestatis institui, in qua hoc ipsum imago et similitudo Dei reputaretur, arbitrii scilicet libertas et potestas. In quam rem ea substantia homini accommodata est, quae huius status esset, adflatus Dei, utique liberi et suae potestatis. Sed et alias quale erat, ut totius mundi possidens homo non inprimis animi sui possessione regnaret, aliorum dominus sui famulus? (tłum. PSP 58, s. 74-75). 
browolnie wybiera dobro, bez żadnego przymusu i determinacji. Już samo dobro zasługuje na to, by podejmować je z ochotą i z własnej woli. Możność dokonywania wyboru i wolna wola stwarzają szanse na rozwój człowieka i doskonalenie, między innymi poprzez przeciwstawianie się złu i panowanie nad sobą. Człowiek gdyby był pozbawiony tego prawa i dobro czynił nie z własnej woli, ale z konieczności, zło uzurpowałoby sobie w przyszłości władzę nad nim, na skutek jego słabości. Wobec tego zarówno w czynieniu zła, jak i dobra człowiek byłby sługą ${ }^{75}$.

Tertulian przyznaje, że dusza jest grzeszna i słaba, ale nie przez fakt, że pochodzi od Boga, lecz na skutek złego użycia wolnej woli:

Dusza nie zgrzeszyla z racji tego, co w niej jest pokrewne Bogu, to jest tchnienia, ale z powodu tego, co doszło do jej substancji, czyli wolnego wyboru danego jej przez Boga, oczywiście rozumnie, a przez człowieka użytego niewłaściwe w sposób dobrowolny ${ }^{76}$.

Wolna wola jest władzą i sprawnością duszy ${ }^{77}$. Ta potestas libera arbitrii, po

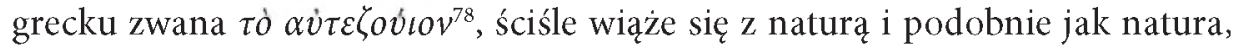
skłaniać może się ku dobremu lub ku złemu. Jest to działanie po linii moralnej, z czego musi rodzić się odpowiedzialność, która spada nie na Boga, jako dawcę wolnej woli, ale na człowieka, jako jej pana i użytkownika ${ }^{79}$. To nie Bóg jest zatem winien zła, które czyni człowiek. Tertulian przekonuje o błędności poglądów

75 Por. TAMżE, II, 6, 5, CCL 1, s. 482: Ut ergo bonum iam suum haberet homo, emancipatum sibi a Deo, et fieret proprietas iam boni in homine et quodammodo natura, de institutione adscripta est illi quasi libripens emancipati a Deo boni libertas et potestas arbitrii, quae efficeret bonum ut proprium iam sponte praestari ab homine, - quoniam hoc et ratio bonitatis exigeret, voluntarie exercendae, ex libertate scilicet arbitrii, non favente institutioni non serviente - ut ita dernum bonus consisteret homo, si secundum institutionem quidem, sed ex voluntate iam bonus inveniretur, quasi de proprietate naturae, proinde ut et contra malum - nam et illud utique Deus providebat - ut fortior homo praetenderet, liber scilicet et suae potestatis, quia si careret hoc iure, ut bonum quoque non voluntate obiret sed necessitate, usurpabilis etiam malo futurus esset ex infirmitate servitii, proinde et malo sicut bono famulus. Por. także: J. AleXANdre, Une Chair Pour La Gloire, dz. cyt., s. 169.

76 TAMżE, II, 9, 8, CCL 1, s. 486: Itaque non per illud iam videri potest anima deliquisse, quod illi cum Deo adfine est, id est per adflatum, sed per illud, quod substantiae accessit, id est per liberum arbitrium, a Deo quidem rationaliter adtributum, ab homine vero qua voluit agitatum. (tłum. PSP 58, s. 80 ).

77 Por. Adversus Marcionem II, 5, 6, CCL 1, s. 481: bo ona (dusza) zapewnia mu wolność jego sądu i moźność wyboru. (tłum. PSP 58, s. 74).

78 Por. De anima 21, 6, CCL 2, s. 814.

${ }^{79}$ Adversus Marcionem II, 6, 1, CCL 1, s. 481: Sed quoniam ex hoc iam intellegimur eo struentes liberam hominis potestatem arbitrii sui, ut quod ei evenit non Deo, sed ipsi debeat exprobrari, ne et tu hinc iam opponas non ita illum institui debuisse, si libertas et potestas arbitrii exitiosa futura esset, hoc quoque prius defendam ita institui debuisse, quo fortius commendem et ita institutum et digne Deo institutum, potiore ostensa ea causa, quae ita fecit institui. 
Marcjona i wykazuje, że dar wolnej woli rodzi osobistą odpowiedzialność każdego za dobro i zło ${ }^{80}$.

A więc cała wolność wyboru udzielona mu została na obydwie strony, aby się okazywat stale panem samego siebie tak $w$ ochotnym zachowaniu dobra, jak $i \mathrm{w}$ dobrowolnym unikaniu zła. Bo i zinnej strony wypadało, aby człowiek postawiony na sadzie Boskim okazal się sprawiedliwym na mocy zasług swojej woli, oczywiście wolnej ${ }^{j 1}$.

Wolność, która jednak poprzez wybory prowadzi do zła, jest wolnością chorą i skarłowaciałą; aby wybierać dobrze, potrzeba woli dojrzałej, która potrafi dostrzec dobro i zaangażować się $w$ służbę dobra ${ }^{82}$. Wymaga to umiejętności wyboru wartości wyższych od niższych i systemu np. prawa, który te wartości wskazuje. Takie prawo daje Bóg. Człowiek, gdyby nie posiadał wolnej woli i możliwości dokonywania wyboru, nie otrzymałby od Boga żadnych przepisów prawnych i przykazań. Podobnie, Bóg by nie upominał, nie karcił i nie pouczał, gdyby człowiek nie ponosił odpowiedzialności za własne czyny, to znaczy dokonywane wybory i okazywaną wzgardę lub posłuszeństwo wobec Bożego prawa. Bóg nie nakładałby też żadnej sankcji na człowieka i zagrożenia śmiercią za popełnione wykroczenia ${ }^{83}$.

Wolna wola oraz odpowiedzialność za zło i dobro słusznie domaga się nagrody i kary dla człowieka za dokonane wybory i czyny:

Zresztq ani zapłaty za dobro, ani kary za zło nie można by wypłacać słusznie i sprawiedliwie człowiekowi, który by się okazał dobrym lub zlym z konieczności, a nie wolnej woli. A i Prawo ustanowione zostato na to, by nie wykluczato wolności, lecz jq aprobowało przez nagrodę za posłuszeństwo okazywane mu dobrowolnie lub przez kare za przekroczenie go $z$ wlasnej woli. Tak w obydwu skutkach ujawnila się wolność wybori ${ }^{84}$.

80 Por. M. Menghi, La corporietà dell'anima e l'innocenza della carne, dz. cyt., s. 25.

81 Adversus Marcionem II, 6, 6, CCL 1, s. 482: Tota ergo libertas arbitrii in utramque partem concessa est illi, ut sui dominus constanter occurreret et bono servando et malo sponte vitando, quoniam et alias positum hominem sub iudicio Dei oportebat iustum illud efficere de arbitrii sui meritis, liberi scilicet. (tłum. PSP 58, s. 76).

82 Por. J. Galarowicz, Na ściezkach prawdy, dz. cyt., s. 546.

83 Por. Adversus Marcionem II, 5, 7, CCL 1, s. 480-481: Non enim poneretur lex ei, qui non haberet obsequium debitum legi in sua potestate, nec rursus comminatio mortis transgressioni adscriberetur, si non et contemptus legis in arbitrii libertatem homini deputaretur. Sic et in posteris legibus creatoris invenias, proponentis ante hominem bonum et malum, vitam et mortem, sed nec alias totum ordinem disciplinae per praecepta dispositum a vocante Deo, et minante et hortante, nisi et ad obsequium et ad conternptum libero et voluntario homini. Por. Pwt 30, 15.19.

${ }^{84}$ Adversus Marcionem II, 6, 7, CCL 1, s. 482: Ceterum nec boni nec mali merces iure pensaretur ei, qui aut bonus aut malus necessitate fuisset inventus, non voluntate. In hoc et lex constituta est. 
Nie należy zatem Boga oskarżać za to co się dzieje, ale ludzkie wybory. Bóg szanuje wolną wolę i pozwala korzystać z tego daru, nawet wtedy, gdy człowiek używa go źle ${ }^{85}$. Bóg nie chce grzechu i zła, ale raz udzielonego daru wolności nie cofa i nie ingeruje, gdy człowiek go nadużywa, gdyż jest on jednym z elementów konstytutywnych człowieka. Bóg konsekwentnie dopuszcza zatem, aby człowiek zgodnie z własnym duchem i rozumem używał wolności bez ograniczeń, nawet ze zgubnymi skutkami dla samego siebie ${ }^{86}$. Gdyby Bóg interweniował, przeszkodził w czynieniu zła na mocy swej opatrzności i potęgi czy wiedzy, byłby oskarżony o niestałość w tym, co sam ustanowił ${ }^{87}$. Człowiek osobiście ponosi winę za grzech i upadek:

A więc, jak Bóg wprowadził czlowieka do stanu życia, tak czlowiek ściagną na siebie stan śmierci, i to nie przez słabość jak i przez nieświadomość, aby tu czegoś nie przypisano Stwórcy. Bo choć ten, co uwiód, był aniołem, to ten, co został skuszony, byt wolnym i panem siebie samego i wyraźniejszym od anioła obrazem i podobieństwem Boga, bo otrzymat tchnienie ducha w materie $e^{88}$.

Należy więc zrozumieć, że wina za grzech obciąża duszę ludzką, nie dlatego, że jest ona tchnieniem Boga, ale na skutek niewłaściwego użycia przynależnej jej władzy wolnej woli i wyboru:

Przeto można spostrzec, ze dusza nie zgrzeszyła z racji tego, co w niej jest pokrewne Bogu, to jest tchnienia, ale z powodu tego, co doszlo do jej substancji, czyli wolnego wyboru danego jej przez Boga, oczywiście rozumnie, a przez czlowieka użtego niewłaściwie w sposób dobrowolny ${ }^{89}$.

non excludens, sed probans libertatem de obsequio sponte praestando vel transgressione sponte committenda: ita in utrumque exitum libertas patuit arbitrii. (thum. PSP 58, s. 76).

85 Por. TAMŻE, II, 7, 1, CCL 1, s. 482.

86 Por. TAMŻE, II, 7, 2, CCL 1, s. 482-483.

87 Por. TAMŻE, II, 7, 4, CCL 1, s. 483. W polemice z Marcjonem Tertulian udowadnia, że taka postawa Boga jest wyrazem Jego dobroci; na temat dobroci Boga w relacji do Jego wolności por. S. StręKowski, Wolność Boga według Tertuliana. Uwagi literackie, ST 16(1998), s. 194; por. też: S.A. Panimolle, Dio Padre negli scritti di Tertulliano, DSBP 1, s. 250-251; T.G. Ring, Auctoritas bei Tertullian, Cyprian, und Ambrosius, Würzburg 1975, s. 58-60.

${ }_{88}$ Adversus Marcionem II, 8, 2, CCL 1, s. 484: Igitur sicut Deus homini vitae statum induxit, ita homo sibi mortis statum adtraxit, et hoc non per infirmitatem, sicuti nec per ignorantiam, ne quid auctori imputaretur. Nam etsi angelus qui seduxit, sed liber et suae potestatis qui seductus est, sed imago et similitudo Dei fortior angelo, sed adflatus Dei generosior spiritu materiali, quo angeli constiterunt. (tłum. PSP 58, s. 78).

${ }^{89}$ TAMżE, II, 9, 8, CCL 1, s. 486: Itaque non per illud iam videri potest anima deliquisse, quod illi cum Deo adfine est, id est per adflatum, sed per illud, quod substantiae accessit, id est per liberum arbitrium, a Deo quidem rationaliter adtributum, ab homine vero qua voluit agitatum. (tłum. PSP 58, s. 80). Por. także: J. AleXandre, Une Chair Pour La Gloire, dz. cyt., s. 171-172. 
Człowiek jako stworzenie Boże (substantia animae), obdarzony wolną wolą i władzą nad sobą, może też odnieść zwycięstwo nad szatanem przez zachowanie Bożego prawa. Bóg nie nakładałby tego prawa, nie zagroziłby wyrokiem śmierci, ani nie obdarzyłby człowieka wolną wolą, gdyby ten faktycznie był zbyt słaby ${ }^{90}$; właściwe użycie wolnej woli przynosi człowiekowi zwycięstwo:

Odłożyl bowiem walkę [Bóg], aby i człowiek za pomocq tej samej wolności woli, która mu przypadła, utrącit wroga, dając dowód swojej, a nie Boga winy, i tak aby z godnościa odzyskal zbawienie droga zwycięstwa ${ }^{91}$.

Tertulian nie zatrzymuje się zatem na wymiarach metafizycznych bytu ludzkiego, ale mówiąc o wolnej woli i wolności osobistej człowieka przenosi akcent na konkretne działania. Dlatego też, jak zaznacza S. Strękowski, „w wyrażeniu "secundum imaginem et similitudinem fieri» należy widzieć działanie ludzkie jako realizację zadań wolnej woli, a przez to nabiera ono cech działania niezależnego i suwerennego i przez to naśladuje Boga, ponieważ Jego działanie jest w pełni suwerenne" ${ }^{29}$. Jednocześnie Bóg, ponieważ jest wszechmocny i wolny, może nadać prawo i zaproponować swoją wolę zbawczą w sposób prawomocny temu wszystkiemu, co do Niego należy ${ }^{93}$. Doskonały, wszechmocny i wolny Bóg może pragnąć tylko dobra stworzeń, dlatego Jego wola wychodzi na spotkanie wolności człowieka, nie przekreśla jej, ale ją uszlachetnia i wywyższa, i pomaga człowiekowi dobrze z niej korzystać na drodze uświęcenia i zbawienia ${ }^{94}$.

Chrześcijaństwo wnosiło w świat starożytny całkowicie nowe spojrzenie na wiele spraw. Tak było też w kwestii rozumienia woli i ludzkiej wolności. Różnicę między tymi dwiema koncepcjami trafnie ukazuje M. Pohlenz, którego wypowiedź warto w tym miejscu przytoczyć: „Wolność rozumiana po grecku jest samodeterminacją człowieka naturalnego; wolność w ujęciu Pawła jest wyzwoleniem spod władzy grzechu, dokonanym przez Boga, jest odkupieniem. Pojęcie odkupienia jest

${ }_{90}$ Por. Adversus Marcionem II, 8, 3, CCL 1, s. 848: Atque adeo eundem hominem, eandem substantiam animae. eundem Adae statum eadem arbitrii libertas et potestas victorem efficit hodie de eodem diabolo, cum secundum obsequium legum Dei administratur.

${ }_{91}$ TAMżE, II, 10, 6, CCL 1, s. 487-488: Certamini enim dedit spatium, ut et homo eadem arbitrii libertate elideret inimicum, qua succiderat illi, probans suam, non Dei culpam, et ita salutem digne per victoriam recuperaret, et diabolus amarius puniretur ab eo, quem eliserat ante, devictus. (tłum. PSP 58, s. 81).

92 S. STRĘKowski, Wolność osobista człowieka wedtug Tertuliana, art. cyt., s. 178; por. Tertuliano, La testimonianza dellanima, Introduzione, traduzione e note di P.A. Gramaglia, Roma 1982, s. 199.

93 Por. A. Solignac, La liberté chez les Peres de L'Église, DS 9, kol. 812.

94 Por. S. Strękowski, Wolność Boga wedlug Tertuliana, dz. cyt., s. 198. 
całkowicie obce Grekom. Mieli oni misteria, które pozwalały wtajemniczonemu spodziewać się szczęśliwego losu po śmierci, ale nie oznaczało to odkupienia od winy. Istniały także sekty, które wierzyły w metempsychozę i za cel stawialy sobie odkupienie od ziemskich zbałamuceń; ale jego urzeczywistnienie było dziełem człowieka. Idea zbawiciela wysłanego przez Boga, który mógłby odkupić od grzechu, była im całkowicie obca, nie mniej obca niż stan ducha Pawła, który czuł wzdychanie stworzenia oczekującego na odkupienie (Rz 8, 22). Dla Pawła właśnie idea odkupienia jest niezwykłą wiadomością, którą szerzy on jako dobrą nowinę. To nie ze świata greckiego mógł zaczerpnąć inspirację [...]”95.

Z mitu orfickiego wynikało, że to ciało nosi na sobie piętno skazy i nieczystości. Nie mniej jednak to dusza została obarczona w sensie ontycznym i etycznym ciężarem przestępstwa i winy, które legły u podstaw antropogenezy ${ }^{96}$. Także dla podzielających poglądy Platona, trudno było zrozumieć i przyjąć naukę o zmartwychwstaniu ciał, po co bowiem wskrzeszać więzienie, skoro dopiero po uwolnieniu się od ciała, po śmierci, dusze mogą być prawdziwie wolne ${ }^{97}$. Także dla gnostyków sięgających do myśli orfickiej czy też pitagorejsko-platońskiej, ciało jawiło się jako przeszkoda do zbawienia. Tym co istotne był sam intelekt bez ciała. Człowiek bezcielesny zatem, to człowiek gnostycki i jego zmartwychwstanie nie jest niczym innym, jak tylko aktem inteligencji, świadomości, w której dochodzi do uznania samego siebie w momencie, kiedy intelekt oczyszczony $\mathrm{z}$ wszelkiego kontaktu z ciałem spotyka się z intelektem powszechnym człowieka przebóstwionego ${ }^{98}$. Gnostycy, którzy pod wpływem platonizmu ciało uważali za wroga duszy, a prawdziwą naturę człowieka identyfikowali z jego duszą, uznawali, że dusze bezpośrednio po śmierci będą przyjęte do nieba i uwolnione od ciężaru ciała, od razu ujrzą Boga takim, jakim jest ${ }^{99}$. Chrześcijaństwo ortodoksyjne przyjmując zbawienie całego człowieka, głosiło również zmartwychwstanie ciała.

W De resurrectione mortuorum już na początku Tertulian przedstawia dwie powszechne wówczas teorie dotyczące losów ludzi po śmierci. Pierwsza podkreślała, że nic nie może żyć po śmierci i wraz z nią wszystko się kończy. Druga zakładała, że w człowieku są dwie substancje, dusza i ciało, ale jedynie dusza może mieć jakąś możliwość i formę przeżycia ${ }^{100}$.

95 M. Pohlenz, La libertà greca, Brescia 1963, s. 230 n.; cyt. za: G. ReAle, Historia filozofii starożytnej, dz. cyt., t. V, s. 256-257.

96 Por. J. Kosiewicz, Myśl wczesnochrześcijańska i katolicka wobec ciała, dz.cyt., s. 26.

97 Por. S. stręKOwsKi, Godność ciala w polemice Tertuliana, dz. cyt., VoxP 22 (2002) t. 42-43, s. 377.

98 Por. E. Peterson, Luomo disincarnato, w: Umanesimo e mondo cristiano, Roma 1951, s. 115; P. Siniscalco, Ricerche sul «De resurrectione» di Tertulliano, dz. cyt., s. 113.

99 Szerzej na ten temat u gnostyków por.: C. Tiвilet ti, Le anime dopo la morte, dz. cyt., s. 642-646.

${ }^{100}$ Por. Tertulliano, La resurrezione dei morti, Traduzione, introduzione e note di C. Micaelli, dz. cyt., s. 20-22. 
Opierając się na nauce św. Pawła (Kol 1, 2; Ga 5, 5; Flp 3, 12), Tertulian przyjmował podwójne zmartwychwstanie duszy: zmartwychwstanie duchowe (prima resurrectio) i zmartwychwstanie cielesne (secunda resurrectio) ${ }^{101}$. Zmartwychwstanie duchowe następuje zaraz po śmierci, w różnym czasie dla każdego człowieka i polega na zniszczeniu wszelkiego grzechu człowieka oraz zakorzenieniu się w Chrystusie ${ }^{102}$. Przy końcu świata dokona się natomiast zmartwychwstanie cielesne, w tym samym i realnym ciele, w jakim człowiek żył na ziemi $^{103}$. Wówczas nastąpi sąd ostateczny nad wszystkimi ludźmi i zapadną ostateczne wyroki ${ }^{104}$.

Tertulian przyjmował dwustopniowość zarówno szczęścia, jak też potępienia w życiu przyszłym, mianowicie zaraz po śmierci w wymiarze czasowym w otchłani i po zmartwychwstaniu ciał w wymiarze wiecznym. Wskazuje na to użycie odpowiedniej terminologii. Mówiąc o czasowym szczęściu dusz po śmierci, obok wyrażenia „miejsce wytchnienia” (refrigerium) Tertulian używał takich określeń jak: tymczasem (interim), w otchłani (apud (penes) inferos), na łonie Abrahama (in sinu Abraham), które wskazują na czasowość tego stanu. Kiedy mówił o szczęściu wiecznym zbawionych, refrigerium określał jako: aeternum, sempiternum, czyli wieczne. Podobnie dusze potępionych po śmierci otrzymują czasową karę w otchłani, a po sądzie ostatecznym idą na wieczne potępienie (w dzisiejszej terminologii do piekła). Mówiąc o karze po śmierci Kartagińczyk stosował określenia: męka (cruciatus), zguba, zagłada (exitium), piekło (gehenna), ogień (ignis), kara (poena), zatrata, katusze (supplicium), męczarnie (tormentum); odpowiednio dodając przymiotnik: wieczny, ustawiczny, wiecznotrwały (aeternus, perpetuus, sempiternus) $)^{105}$.

${ }^{101}$ Por. G. BARDY, Résurrection, Dictionnaire de Théologie Catholique 13, 2524. Tertulian wyjaśnia, że w ścisłym słowa znaczeniu zmartwychwstanie może dotyczyć właściwie ciała, gdyż powstać może tylko to, co wcześniej upadło i powstać z martwych może tylko to, co wcześniej umarło, dusza natomiast w swej istocie jest nieśmiertelna (por. np. De resurrectione mortuorum 18, 4-9, CCL 2, s. 942; Adversus Marcinem V, 9, 4, CCL 1, s. 689). Z tego względu Kartagiński pisarz często używał określeń: carnis resuscitator, carnem resuscitsre, resurget caro, corporalis resurrectio, corporaliter resurgere, carnis redintegratio, por. R. BRAUN, «Deus Christianorum», dz. cyt., s. 530n.; P. Siniscalco, Ricerche sul «De resurrectione» di Tertulliano, dz. cyt., s. 101-103. Poganie i gnostycy uważali, że element zmysłowy i widoczny w człowieku jest w zupełności niegodny, by uczestniczyć $\mathrm{w}$ zbawieniu, dlatego Tertulian podejmował z nimi polemikę, wykazując, że jedynie formalnie i powierzchownie zgadzają się z chrześcijaństwem ci, którzy uczą jedynie o zbawieniu duszy i tylko o zmartwychwstaniu duchowym, co najwyżej ciała duchowego; por. P. SinisCalco, Ricerche sul «De resurrectione» di Tertulliano, dz. cyt., s. 104.

102 Por. De resurrectione mortuorum 23-32, CCL 2, s. 949-962; J. TurmeL, Tertullien, dz. cyt., s. 273-275; J. DANIÉLOU, Les orígines du christianisme latin, dz. cyt., 312-315.

${ }_{103}$ Na temat integralności i identyczności substancji ciała zmartwychwstałego w ujęciu Tertuliana por. P. Siniscalco, Ricerche sul «De resurrectione» di Tertulliano, dz. cyt., s., 154-167.

${ }_{104}$ Por. De resurrectione mortuorum 35-37, CCL 2, s. 966-970.

${ }^{105}$ Por. K. OвRYCKI, Los złych po śmierci wedtug Tertuliana, VoxP 10 (1990) z. 19, s. 602-603; szerzej: TenżE, Refrigerium u Tertuliana, w: Tertulian, Wybór pism, II, PSP 29, Warszawa 
Tertulian jest zdecydowanym obrońcą teorii o przebywaniu wszystkich dusz w otchłani aż do dnia Sądu ostatecznego. Skoro sam Chrystus Bóg-Człowiek zstąpił do otchłani i przebywał we wnętrznościach ziemi, tym bardziej ten sam los czeka ludzi, którzy są jedynie sługami Pana i nie są nad swego Mistrza. Byłoby wyrazem ogromnej pychy twierdzić inaczej i odrzucać możliwość odbierania pociechy na łonie Abrahama w oczekiwaniu na zmartwychwstanie ${ }^{106}$. Wszystkie dusze są zatem godne przebywania w otchłani. Pojawiały się argumenty, iż Chrystus dlatego zstąpił do otchłani, aby wierni tam nie poszli, jak również, że byłoby niesprawiedliwe ustawianie pogan na równi z chrześcijanami i umieszczanie ich po śmierci w tym samym więzieniu. Tertulian wyjaśniał jednak, że nie ma innej możliwości przejścia po nagrodę wieczną w Królestwie niebieskim, jak tylko dopiero przy powtórnym przyjściu Chrystusa, gdy zagrzmi głos trąby i nastanie dzień Sądu oraz powszechne zmartwychwstanie ${ }^{107}$ :

Dla nikogo niebo nie stoi otworem, jak dlugo ziemia istnieje, by nie powiedzié,, jak dlugo jest zamknięta. Dopiero za przemiana świata otworza się królestwa niebieskie ${ }^{108}$.

Dusze złych po śmierci, również przechodzą do otchłani, ale zajmują miejsce różne od łona Abrahama. Jest to przestrzeń kary i zadośćczynienia Bogu za popełnione zło. Miejsca tego Tertulian bliżej nie określa i nie nadaje mu specjalnej nazwy, ale jest to również miejsce oczekiwania na ostateczny wyrok w dniu sądu ostatecznego i powszechnego zmartwychwstania. Dusze potępionych przy duchowym zmartwychwstaniu (prima resurrectio) od razu otrzymają należną sobie karę. Nie będą mogły już od niej nigdy się uwolnić ani przejść do miejsca ochłody (refrigerium). Przy zmartwychwstaniu ciał (secunda resurrectio), na sądzie ostatecznym kara ta zostanie definitywnie zatwierdzona przez Chrystusa, jako kara wiecznego potępienia ${ }^{109}$.

1983, s. 34-42; użycie omawianej terminologii patrz odpowiednie hasło w: G. ClaEsson, Index Tertullianeus, Paris 1975, t. 1-3.

${ }^{106}$ Por. De anima 55, 2, CCL 2, s. 862.

${ }^{107}$ Por. 1 Tes 4, 13-17: Nie chcemy, bracia, waszego trwania w niewiedzy co do tych, którzy umierają, abyście się nie smucili jak wszyscy ci, którzy nie majq nadziei. Jeżeli bowiem wierzymy, że Jezus istotnie umarl i zmartwychwstal, to również tych, którzy umarli w Jezusie, Bóg wyprowadzi wraz z Nim. To bowiem głosimy wam jako słowo Pańskie, że my, żywi, pozostawieni na przyjście Pana, nie wyprzedzimy tych, którzy pomarli. Sam bowiem Pan zstapi z nieba na hasło i na glos archanioła, i na dźwięk trąby Bożej, a zmarli w Chrystusie powstanq pierwsi. Potem my, żywi i pozostawieni, wraz z nimi będziemy porwani w powietrze, na obloki naprzeciw Pana, $i$ w ten sposób zawsze będziemy z Panem.

${ }^{108}$ De anima 55, 3, CCL 2, s. 862: Nulli patet caelum terra adhuc salva, ne dixerim clausa. Cum transactione enim mundi reserabuntur regna caelorum.

${ }^{109}$ Por. De anima 55-58, CCL 2, s. 861-869; Adversus Marcionem I, 26, CCL 1, s. 469-470; TAMżE, I, 28, CCL 1, s. 472-474; TAMżE, II, 11, CCL 1, s. 488-489; TAMŻE, II, 13, CCL 1, s. 489-491; 
Pojawiał się problem, czy dusza oddzielona przez śmierć od ciała, może bez niego doznawać nagrody lub kary w otchłani? K. Obrycki zwraca uwagę, że kwestia ta, przysporzyła Tertulianowi nieco trudności ${ }^{110}$. W Apologeticum 48, czy też w De anima 7 możemy najpierw przeczytać, że dusza dopóki nie połączy się z ciałem przy zmartwychwstaniu, nie może niczego odczuwać, ani działać. Później jednak Kartagińczyk, opowiadając się za cielesnością duszy, przyznał jej zdolność odczuwania bólu i radości także w otchłani, ale w stopniu niedoskonałym:

Iléz razy dusza sama, bez doznań ciała, jest dręczona przez gniew, złość, wstręt, najczęściej nie zdając sobie z tego sprawy? Ile razy w taki sam sposób kiedy cierpi cialo, dusza szuka dla siebie ukrytej przyjemności i oddala się od przykrego wówczas zwiazku z ciaŁem? Skłamalbym, gdybym nie przyznat, że dusza sama ma niekiedy zwyczaj cieszyć się i radować $z$ owych cierpień ciała. [...] Dlatego też $i$ w otchlani dusza bez ciała potrafi doświadczać przyjemności i cierpienia, jakoże jeśli chce, doznaje cierpienia wewnatrz ciala, które nie cierpi i jeśli chce, raduje się $w$ ciele cierpiacym. Jeżeli tak dzieje się za zycia na skutek jej wyboru, tym bardziej dojdzie do tego po śmierci z wyroku Boga ${ }^{111}$.

Ostatecznie Tertulian uznał za niedorzeczność i naiwność odmawianie duszy możności doznawania udręki czy też ulgi w otchłani ${ }^{112}$. Jako przykład zdolności duszy do samodzielnego odbierania odmiennych doznań od ciała, Kartagińczyk przywołuje postawę Mucjusza Scewoli ${ }^{113}$, Zenona ${ }^{114}$ i Cyrusa ${ }^{115}$, w momencie, gdy doznawali cierpień fizycznych (De anima 58,5 ). Dla zobrazowania sytuacji w otchłani przedstawił ewangeliczną przypowieść o bogaczu i Łazarzu, którzy chociaż pozbawieni swoich cial, jednak odpowiednio doznawali boleści i wytchnienia ${ }^{116}$. W taki oto sposób wykazuje, że dusza skoro jest zdolna do doznań bez udziału ciała, będzie mogła doświadczać nagrody lub kary także w otchłani jeszcze przed zmartwychwstaniem, zanim powtórnie połączy się z ciałem.

TAMżE, IV, 34, CCL 1, s. 634-635; K. OBRYCKI, Los zlych po śmierci wedlug Tertuliana, dz. cyt., s. 607.

${ }^{110}$ Por. K. OBRYckI, Los zlych po śmierci wedhug Tertuliana, dz. cyt., s. 601.

111 De anima 58, 4-5, CCL 2, s. 868: Quotiens inlaeso corpore anima sola torquetur bile ira taedio plerumque nec sibi noto? Quotiens item corpore afficto furtivum sibi anima gaudium exquirit et a corporis tunc importuna societate secedit? Mentior, si non de ipsis cruciatibus corporis et gloriari et gaudere sola consuevit. [...]

Adeo novit et apud inferos anima et gaudere et dolere sine carne quia et in carne et inlaesa si velit dolet et laesa si velit gaudet. Hoc si ex arbitrio suo in vita, quanto magis ex iudicio Dei post mortem?

${ }_{112}$ Por. De resurrectione mortuorum 17, CCL 2, s. 941-942.

113 Przykład często podawany przez apologetów i pisarzy; por:: Ad nationes 1, 18, 3-4, CCL 1, s. 37; Minucius Felix 37, 3, CSEL 2, s. 52; Lactantius, Divinae institutiones 5, 13, 13, w: Lactance, Institutions Divines livre V, Introduction, texte critique, traduction par P. Monat, SCh 204, Paris 1973, s. 196; Augustinus, De civitate Dei 4, 20, CCL 47, s. 114; tamże 5, 18, CCL 47, s. 152.

114 Por. Apologeticum 50, 9, CCL 1, s. 170.

115 Por. Ksenofont, Anabasis 1, 9, 6, w: Xénophon, Anabase, Paris 1930, t. 1, s. 82. 


\title{
5. Podsumowanie
}

W kontekście historycznym myśli antropologicznej poglądy Tertuliana dotyczące duszy i jej relacji do ciała są bardzo istotne. Trzeba bowiem pamiętać, że w pierwszych dwu wiekach autorzy chrześcijańscy musieli przeciwstawić się poglądom orficko-platońskim pogardzającym ciałem ludzkim i traktującym je jako więzienie duszy. Podobne teorie powracały w gnozie i stwarzały zagrożenie dla myśli ortodoksyjnej. Kolejne niebezpieczeństwo wiązało się z doketyzmem, który głosił pozorność ciała Chrystusa, co także rodziło poważne problemy doktrynal$\mathrm{ne}^{117}$. W powstającej chrześcijańskiej koncepcji antropologicznej zaznaczyły się dwa aspekty, skrypturystyczny i doktrynalny. Dobra znajomość Pisma św. i przywiązanie do niego pozwalało chrześcijańskim autorom, także tym wywodzącym się z pogaństwa, w sposób nowy patrzeć na ludzkie ciało, przede wszystkim rozumiane jako rzeczywistość neutralna i niegrzeszna sama w sobie, albo pojmowane jako integralna osoba stosownie do własnego wyglądu fizycznego.

$\mathrm{Z}$ drugiej strony szerzące się herezje skłoniły także chrześcijan do większego szacunku dla ciała, podkreślania jego godności i podejmowania wizji anty-dokestycznych ${ }^{118}$. Za argumentami ukazującymi czystość i godność ciała, szly argumenty podkreślające jedność człowieka, ale zarazem indywidualność i odpowiedzialność tak duszy jak i ciała. Przeznaczenie człowieka do zbawienia sugerowało udział obu tych substancji w wydarzeniach eschatologicznych, co niosło ze sobą konieczność współuczestnictwa ciała i duszy przed trybunałem Boga na sądzie oraz w wiecznej karze lub nagrodzie.

\section{Body - source of sin or cause to glory according to Tertullian}

\author{
SUMMARY
}

The article considers human body in teaching of Tertullian, one of the famous early Christian writers and an important apologist of Christianity. It consists of five parts: 1. Introduction; 2. Despise body in ancient philosophical thought; 3. Dignity of body according to Tertullian; 4. Human body and responsibility for evil and sin; 5. Summary.

\footnotetext{
116 Por. De resurrectione mortuorum 17, CCL 2, s. 941-942. Łk 16, 19-31.

117 Por. R. Cantalamessa, La cristologia di Tertulliano, dz. cyt., s. 120-125.

${ }^{118}$ Por. P. Siniscalco, Ricerche sul „De resurrectione” di Tertulliano, dz. cyt., s. 135-136.
} 